JIIP: Jurnal IImiah IImu Pemerintahan

Volume 5, Nomor 2, Tahun 2020

DOI: $10.14710 /$ jiip.v5i2.8699

\title{
Pandemi Covid-19 dan Pendekatan Kebijakan Multikrisis: \\ Sebuah Refleksi Teoritis
}

\author{
Laila Kholid Alfirdaus ${ }^{1}$, Teguh Yuwono ${ }^{2}$ \\ 1,2 Prodi Ilmu Pemerintahan, Universitas Diponegoro
}

Dikirimkan: 14 Agustus 2020

Direvisi: 28 September 2020

Diterbitkan: 30 September 2020

\section{INTISARI}

Pandemi yang diakibatkan infeksi Covid-19 sejak akhir 2019 hingga saat ini memberikan pelajaran baru atas pendekatan kebijakan. Selama ini, ilmuan cenderung melihat kebijakan pada dari dua kutub pendekatan, yaitu kebijakan sebagai business as usual dan kebijakan di masa krisis. Munculnya pandemi ini rupanya menghadirkan tantangan yang jauh lebih besar dari apa yang dibayangkan dalam kebijakan dalam situasi krisis. Mulai dari ketidakjelasan informasi tentang virus, ketidakpastian berakhirnya penularan, dilema prioritas kesehatan dan ekonomi, terbatasnya sumberdaya yang dimiliki, adalah beberapa persoalan global yang terus mencuat di tengah tekanan publik yang makin besar terhadap kebijakan pemerintah. Artikel ini berusaha mengurai kerumitan kebijakan dalam konteks Covid-19, yang penulis sebut sebagai kebijakan multi-krisis. Dengan mengandalkan pada penelitian sekunder dengan sumber utama adalah dokumen-dokumen literatur, maka artikel ini adalah tawaran ide dalam mengkerangkai teori kebijakan.

business as usual; Covid-19; kebijakan multikrisis; situasi krisis; teori kebijakan

\section{Pendahuluan}

rtikel ini mendiskusikan konsep-konsep kebijakan publik yang selama ini
digunakan untuk menjelaskan fenomena sosial dan politik dan bagaimana
konsep-konsep tersebut dalam konteks pandemi ini memerlukan beberapa pemikiran ulang. Jika selama ini para ilmuan mendeskripsikan kebijakan dalam dua ranah, yaitu kebijakan sebagai business as usual, dan kebijakan dalam situasi krisis, artikel ini berargumen bahwa dua pendekatakan ini perlu peninjauan ulang. Mencermati fenomena pandemi, artikel ini melihat kebijakan dalam konteks Covid-19 bukan sekedar kebijakan krisis, tetapi kebijakan multikrisis mengingat besar dan berlipat-gandanya kerumitan dan beban yang harus diurai para pembuat kebijakan, termasuk di negara berkembang seperti Indonesia.

Sebagaimana yang kita ketahui, pandemi ini adalah fenomena global. Tidak ada negara yang bebas dari kasus Covid-19, respon kebijakan masih naik turun, dan 
kemajuan-kemajuan di beberapa negara belum dapat dikatakan sebagai capaian yang mapan atau konsisten. Tidak seperti bencana alam, yang cenderung terjadi pada wilayah regional tertentu, sehingga memungkinkan negara lain membagi konsentrasi dan mengulurkan bantuan, pandemi ini memaksa negara-negara untuk fokus pada penyelesaian kasus domestik terlebih dahulu. Bantuan antar negara memang masih bisa diidentifikasi, tetapi fakta bahwa masing-masing negara memaliki beban tersendiri, menyebabkan penyaluran bantuan tidak optimal.

Di sisi lain, ada banyak tantangan yang membuat para pengambil keputusan tidak mudah mencari jalan keluarnya. Pertama-tama adalah masih minimnya pengetahuan tentang apa itu Covid-19, sehingga di masa-masa awal pandemi, yang notabene adalah masa emas penekanan kasus dapat dikatakan terlewatkan. Banyak kritik dilontarkan, mengarah pada anggapan bahwa pemeirntah tidak serius, menyepelekan, atau mengabaikan. Namun, muara dari semua respon yang tidak optimal adalah minimnya pengetahuan tentang Covid-19, tidak hanya oleh pemerintah, tetapi bahkan di kalangan akademisi. Situasi ini, tentu menyebabkan kesulitan tersendiri.

Berikutnya adalah dilema prioritas kebijakan yang menuntut perhatian secara bersama-sama, sementara sumberdaya cukup terbatas. Beberapa kalangan mendesak pemerintah fokus pada pemulihan kesehatan, dan menganjurkan lockdown, tetapi keterbatasan sumberdaya menyebabkan tidak banyak pilihan yang bisa diambil., sebagai kebijakan jalan tengah, dipilih sebagai opsi untuk menjembatani keparahan New Normal penularan dan keterpurukan ekonomi. Dengan situasi ini, akhirnya para pengambil keputusan tidak bisa menghindari tekanan publik yang bertubi-tubi.

Dengan situasi yang serba rumit, serta beban dan tantangan yang berlipat-ganda ini, artikel ini melihat penjelasan teori kebijakan terkait dengan pendekatan business as usual dan business as crisis rupanya perlu ditilik ulang. Business as usual adalah pendekatan yang menjelaskan beroperasinya kebijakan dalam kehidupan sehari tanpa tekanan krisis, tanpa inovasi dan terobosan yang mendesak (Chirot, 2011: 126). Dalam Bahasa sehari-hari, ini biasa disebut sebagai kebijakan dalam situasi normal, walau istilah 'normal' itu sendiri sarat dengan perdebatan teoritik dan filosofi. Sementara itu, business as crisis merupakan pendekatan yang sebaliknya, yang mencoba menjelaskan beroperasinya kebijakan di situasi krisis, seperti bencana, krisis ekonomi, perang dan wabah (Boin, Hart, \& Kuipers, 2018: 23; Devlin, 2006). Dalam Bahasa sehari-hari, pendekatan ini disebut dengan kebijakan dalam masa krisis.

Sebagian besar ilmuan menggunakan kerangka pendekatan krisis untuk menjelaskan fenomena pandemi. Padahal, mempertimbangkan pengalaman praktis sebagaimana dijelaskan di atas, pendekatan krisis, sebagaimana yang didiskusikan Rodríguez, Donner, \& Trainor (2018), dirasa masih belum cukup untuk menjelaskan fonomena sosial yang melingkupi konteks pandemi akibat kasus Covid-19. Beban dan tantangan yang berlipat ganda, menjelaskan krisis yang berlipat ganda. Untuk itu, artikel ini menawarkan ide pendekatan multikrisis, untuk menjelaskan fenomena pandemi, untuk memperkaya pendekatan kebijakan yang selama ini ada.

Artikel ini didasarkan pada kajian literatur yang mendiskusikan konsep dan pendekatan kebijakan, lalu membandingkannya dengan fenomena pandemi saat ini, untuk memastikan ketercukupan pendekatan-pendekatan tersebut menjelaskan fenomena yang ada. Dengan demikian, penelitian dalam artikel ini adalah penelitian 
sekunder, yang mengandalkan sumber-sumber tertulis lain dalam penyusunan argumentasinya.

\section{Dikotomi Pendekatan Kebijakan: Business as Usual dan Kondisi Krisis}

Dalam kajian kebijakan, setidaknya terdapat dua pendekatan besar yang jamak digunakan untuk menjelaskan operasionalisasi kebijakan merespon berbagai praktik persoalan di masyarakat. Pendekatan itu adalah business as usual dan crisis. Dalam Bahasa yang lebih sederhana, pendekatan ini disebut dengan pendekatan kebijakan dalam situasi normal dan pendekatan kebijakan dalam situasi krisis.

Pendekatan ini didasarkan pemikiran bahwa manusia pada dasarnya selalu menghadapi dua situasi yang berbeda, yaitu situasi normal dan situasi krisis (Wong \& Shi, 2018: 73). Situasi normal adalah situasi yang menunjukkan keadaan biasa saja, bahkan 'baik-baik' saja. Sementara, situasi krisis menunjukkan keadaan yang luar biasa, cenderung menyulitkan dan menyusahkan. Tentu saja, dalam pendekatan konstruktivis, apa yang disebut dengan 'normal', 'biasa', 'baik-baik saja', tidak normal', atau 'krisis' tidak lepas dari pertanyaan, karena sangat tergantung pada siapa mengkonstruksi apa. 'Siapa' mengacu pada subyek pemegang kekuasaan, yang memiliki kuasa untuk mendefinisikan sesuatu atau keadaan atas orang lain sebagai obyek kekuasaan. Namun, penyederhanaan dikotomi situasi ini, disadari membantu memberikan gambaran kasar, tentang dua situasi kontras yang dialami manusia. Kebijakan, sebagai seperangkat instrumen yang dirancang untuk merespon berbagai situasi, akhirnya juga dijelaskan dari pemikiran tersebut, dan membentuk apa yang disebut sebagai kebijakan sebagai business as usual dan kebijakan dalma situasi krisis.

Sebagaimana dijelaskan dalam berbagai literatur, terdapat karakteristikkarakteristik tertentu yang menjelaskan dua pendekatan tersebut yang sekaligus membedakan keduanya. Salah satu kata kunci untuk memahami kedua pendekatan tersebut adalah perihal kepastian (Craig, 2018: 20). Dalam pendekatan kebijakan sebagai business as usual, tujuan, kerangka waktu, keterlibatan publik dan media, sumberdaya dan sumber dana relatif tidak dalam kondisi tekanan. Sebaliknya, kebijakan dalalm kondisi krisis penuh dengan ketidakpastian dan tekanan baik secara internal maupun eksternal pembuat kebijakan.

Dari aspek tujuan, kebijakan dengan pendekatan business as usual dimaksudkan untuk mencapai tujuan yang sudah diproyeksikan sebelumnya. 'Projecticized' organization, sebagaimana yang dijelaskan (Carroll, 2016: 1-2), memungkinkan kebijakan business as usual untuk menyusun tujuan kebijakan dengan desain dan metode yang sistematif dan terukur. Misalnya, pemerintah bermaksud menyelesaikan persoalan infrastruktur jalan. Berapa kilometer jalan yang dibutuhkan untuk dibangun, dibandingkan dengan sumber daya yang dimiliki, akan mudah diukur berapa waktu yang diperlukan, dengan ketentuan tidak ada bencana yang mendadak datang. Jika tidak hambatan mendadak dan mendesak, tujuan mengatasi masalah infrastruktur dapat disusun secara usual.

Dari aspek kerangka waktu, sebagaimana dijelaskan sebelumnya, pendekatan kebijakan mengandaikan pelaksanaan kebijakan bisa dilakukan dalam kurun waktu tertentu. Jangka waktu kebijakan dapat diproyeksikan, misal untuk kurun waktu 1 bulan, 3 bulan, 6 bulan sampai 1 tahun anggaran. Kadang-kadang kebijakan juga bisa bersifat 
multi-tahun. Namun, susunan kerangka waktu ini telah dipersiapkan sebelumnya, sesuai dengan capaian tujuan yang diinginkan serta sumberdaya yang dimiliki.

Dari aspek keterlibatan publik, kebijakan business as usual mengandaikan ruang yang cukup untuk partisipasi publik. Dalam rentang waktu yang sudah disusun, partisipasi publik biasanya diletakkan di bagian perencanaan sebagai bagian untuk menampung masukan dan aspirasi masyarakat. Dalam konteks kebijakan di Indonesia, partisipasi publik secara regulasi kentara dalam tahap perencanaan yang disebut dengan Musrenbang atau Musyawarah Perencanaan Pembangunan. Musrenbang yang pelaksanaannya berjenjang dari tingkat desa, kecamatan, kabupaten, provinsi hingga nasional merepresentasikan pendekatan politik dalam kebijakan, disamping pendekatan teknokratik. Jika pendekatan teknokratik berusaha meletakkan filosopi, rancangan dan desain kebijakan di tangan para ahli, pendekatan politik dimaksudkan untuk mengakomodasi nilai-nilai demokrasi dalam penyusunan kebijakan. Business as usual memungkinkan dua jalur pemberian masukan ini terjadi.

Dari aspek sumber daya dan sumber dana, business as usual mengandaikan informasi yang memadai terkait ketersediaan dan kemampuan sumberdaya dan sumber dana dibandingkan dengan tujuan yang ingin dicapai, serta proporsi pencapaian dalam rentang waktu tertentu. Dengan demikian, kebijakan lebih mudah diproyeksikan dan pengambil kebijakan dapat mengira-ira pencapaian maksimal paling masuk akal dengan sumber daya dan sumber dana yang tersedia.

Sementara itu, kebijakan dalam situasi krisis menjelaskan sebaliknya. Krisis sendiri, sebagaimana Gilpin \& Murphy (2008: 5), didefinisikan sebagai situasi mendesak yang berasal dari faktor eksternal yang memaksa sebuha organisasi untuk memberikan respon langsung. Terdapat banyak ketidak pastian, yang bersamaan dengan besarnya tekanan, dibandingkan pada situasi normal dalam krisis.

Dari aspek tujuan, kebijakan dalam masa krisis justru terbebani tujuan yang lebih kompleks dibanding kebijakan dalam business as usual karena banyaknya elemen yang harus ditekan sekaligus didorong bersamaan. Dalam penanganan bencana, misalnya, jumlah korban harus ditekan, tetapi pemulihan infrastruktur harus disegerakan secara bersamaan. Karena disebabkan oleh faktir eksternal, dalam situasi krisis, tujuan kebijakan tidak bisa ditetapkan sebelumnya. Tujuan tersebut datang seketika, di saat persoalan kebijakan juga muncul. Tujuan kebijakan tidak diinisiasi dan diantisipasi sebelumnya oleh pembuat kebijakan, walaupun terkadang sudah ada prediksi-prediksi peristiwa.

Dari aspek kerangka waktu, kebijakan dalam masa krisis menuntut penyelesaian yang tuntas tetapi dalam waktu yang cepat. Pembuat kebijakan tidak disediakan banyak pilihan waktu kapan menyelesaikan, karena segera, secepat-cepatnya dan setepattepatnya, adalah satu-satunya kerangka waktu yang mungkin diambil. Jika tidak, resiko kerugian, kehilangan atau kerusakan, akan semakin besar. Namun demikian, isu lain dalam kaitannya dengan 'waktu' didalam kebijakan dalam situasi krisis adalah, tidak ada kepastian tenggat waktu ke depan, sampai kapan pengambil kebijakan dimungkinkan untuk bermanuver atau memiliki diskresi dalam kebijakan. Bahkan, 'waktu' menjadi bagian dari tenaga penekan bagi pengambil keputusan, dan terkadang dengan ongkos konsekuensi yang kadang mahal, jika desakan waktu tersebut tidak dapat dipenuhi. 
Dari aspek keterlibatan publik, kebijakan dalam situasi krisis ini jelas akan menemui banyak tekanan dari masyarakat (Arjen Boin, Stern, \& Sundelius, 2016). Kesusahan yang dihadapi membuat masyarakat tidak tahan dan mendesak pembuat kebijakan segera menyelesaikan masalah yang mereka hadapi. Namun demikian, di sisi lain, kebijakan dalam situasi krisis biasanya tidak akan banyak menyediakan ruang untuk diskusi atau dialog. Pengambil keputusan mungkin mafhum terhadap adanya tekanan publik, tetapi mungkin tidak akan banyak akomodasi yang bisa diberikan mengingat desakan percepatan penyelesaian masalah tidak bisa dihindari. Musyawarah perencanaan pembangunan sebagaimana yang mungkin dilakukan dalam konteks business as usual guna menjaring masukan dan aspirasi masyarakat tidak banyak bisa diupayakan. Musawarah atau dialog bahkan dapat dianggap sebagai buang-buang waktu dan energi, sehingga persoalan yang mestinya bisa segera diselesaikan menjadi tertunda. Jika dalam kebijakan business as usual, perencanaan memungkinkan sinkronisasi pendekatan teknokratik dan politik secara bersama-sama, dalam situasi krisis hal ini sulit diwujudkan. Kebijakan akan lebih banyak didominasi para ahli yang memiliki spesialisasi tinggi. Dengan demikian, atmosfer kebijakan akan terlihat sangat teknokratik.

Dari aspek sumber daya dan sumber dana, bisa dikatakan umumnya situasi krisis tidak masuk dalam perencanaan penganggaran. Krisis akan memakan anggaran dari sektor-sektor yang sebelumnya ditetapkan melalui pendekatan business as usual. Realitanya seringkali alokasi yang dibutuhkan tidak kecil (Borodzicz, 2005: 73). Tidak jarang, krisis juga membebani para pembuat kebijakan dengan kebijakan dan sumber daya manusia yang melampau kapasitasnya. Tidak jarang pula, pembuat kebijakan harus menghadapi ketidakpastian krisis berakhir dan berapa sumber daya dan sumber dana lagi yang harus dialokasikan.

Dari paparan di atas, kita dapat melihat sekali lagi, yang membedakan kebijakan dengan pendekatan business as usual dan kebijakan dalam situasi krisis adalah aspek 'kepastian'. Hasilnya, dalam situasi business as usual, kebijakan untuk mencapai tujuan tertentu dapat diproyeksikan kerangka waktunya, sumber daya dan sumber dananya, serta memungkinkan pelibatan partisipasi publik didalamnya guna mempertemukan aspek teknokratik dan aspek politik kebijakan. Sementara itu, dalam situasi krisis, lebih banyak hal yang tidak bisa diprediksi, ditambah lagi pembuat kebijakan sering dihadapkan pada tekanan waktu, tekanan sumberdaya, keterbatasan sumber dana, serta tekanan publik secara bersamaan.

\section{Konteks Pandemi Covid-19 dan Beban Berlipat-ganda Kebijakan}

Pandemi Covid-19 yang diakibatkan infeksi virus Corona baru atau Sars-Cov2 merepresentasikan kerumitan yang berlipat ganda sebuah krisis. Semua aspek dalam konteks Covid-19 mengindikasikan bekerjanya indikator-indikator sebuah kebijakan disebut dalam masa krisis, sebagaimana didiskusikan pada bagian sebelumnya. Dari segi faktor penyebab, tujuan kebijakan, tekanan waktu, keterlibatan publik, sampai ketersediaan sumberdaya pandemi Covid-19, semua mengarahkan pada definisi tunggal bahwa kebijakan berada dalam situasi krisis. Konteks pandemi ini menjadi menarik diamati, bukan sekedar karena kasus ini memenuhi segala macam kriteria untuk disebut 
krisis, tetapi lebih dari itu, kasus ini menunjukkan puzzle kebijakan yang jarang dijumpai sebelumnya.

Pertama-tama, konteks Corona ini memaksa pembuat kebijakan untuk mampu mencari solusi di saat masalah yang dihadapi ini jenis dan definisinya apa masih belum jelas. Ini jelas berbeda dengan konteks krisis dalam bencana alam. Kajian ilmiah tentang gempa bumi, badai, banjir, letusan gunung dan kekeringan sudah sangat masif karena kejadian yang sama yang telah terulang memberikan pelajaran yang berharga bagi pengetahuan. Desain mitigasi menjadi lebih mudah disusun dan diberlakukan. Dalam beberapa waktu terakhir, bahkan pemerintah Indonesia mendapat pujian karena berhasil memitigasi kejadian bencana alam, sehingga terus menerus tingkat keparahan dampaknya makin berkurang.

Sementara itu, informasi dan pengetahuan tentang apa itu Corona sangat terbatas. Dunia akademik juga masih kelabakan mencari tahu virus baru ini. Berbagai respon yang ditunjukkan para pembuat kebijakan di awal-awal menunjukkan betapa mereka masih buta terhadap jenis virus baru ini dan tidak memiliki pengetahuan yang cukup dan pasti tentang bagaimana mengatasinya. Para pembuat kebijakan baru mulai menunjukkan respon serius di saat warga sudah ada yang terinfeksi, tetapi masih dengan langkahlangkah kebijakan yang sangat terbatas. Walaupun berita tentang penyebaran virus ini sudah menyebar di Wuhan, China sejak akhir tahun, banyak pihak, termasuk para pembuat kebijakan, tidak menyangka bahwa virus ini akan begitu cepat pecah di negaranegara lain di dunia, termasuk Indonesia.

Di masa-masa awal pandemi, banyak kritik dilontarkan, mengarah pada anggapan bahwa pemerintah tidak serius, menyepelekan, atau mengabaikan. Kritik ini tidak salah, tetapi tidak juga dapat disangkal pengetahuan tentang Covid-19 juga masih minim, bahkan di kalangan akademisi, sehingga ekspektasi soal penanganan yang cepat dan tepat juga berat diwujudkan. Namun demikian, dari sisi pemerintah, juga dengan jelas terlihat bahwa tidak terjadi proses pembelajaran yang cepat, terkait bagaimana membaca kecenderungan virus dan meresponnya dalam kebijakan, meskipun kasus yang sama sudah pecah di Eropa dan Amerika. Pengorganisasian kebijakan yang tidak rapi, koordinasi yang tidak jalan secara optimal optimal, serta ketegangan antara pemerintah pusat dan daerah yang sangat kentara, menggambarkan bentuk sebagai chaos organisasi dalam krisis. Hasilnya, upaya penekanan penyebaran tidak terpegang.

Kedua, konteks pandemi Covid-19 ini memaksa pembuat kebijakan masuk dalam dilema besar, yaitu antara memberikan fokus total pada sektor kesehatan atau menjaga roda perekonomian nasional. Beberapa kalangan mendesak pemerintah fokus pada pemulihan kesehatan, dan menganjurkan lockdown. Dasar pemikiran usulan ini karena dampak jangka panjang akan lebih besar jika penularan tidak dikendalikan. Menghentikan penyebaran virus adalah satu-satunya jalan. Dengan melakukan lockdown, pemerintah mengisolasi wilayah yang terinfeksi, memulihkan kesehatan penduduk yang terinfeksi tersebut, dan mengurangi kemungkinan daerah lain tersebar. Kalangan ini percaya, selama ada mobilitas, virus tetap tidak terhindarkan. Para pendukung kebijakan lockdown ini beralasan, biaya besar lockdown akan terbayar dengan pemulihan yang cepat.

Namun, pemerintah ternyata memiliki logika sendiri. Penduduk yang jumlahnya ratusan juta, tingkat kedisiplinan yang belum terbentuk, serta ketergantungan ekonomi 
pada kegiatan bergerak, bagi pemerintah, membuat pekerjaan lockdown menjadi tidak mudah. Belum lagi, jika ditambah berbagai komponen biaya, melakukan lockdown menjadi sangat mahal, sementara sumberdaya yang tersedia terbatas. Akhirnya, langkah yang diambil adalah Pembatasan Sosial Berskala Besar (PSBB) di daerah-daerah yang dirasa kasus penularannya parah, dengan ketentuan, penetapannya dikendalikan oleh pusat. PSBB diterapkan berdasarkan pengajuan pemerintah daerah yang merasa infeksi Corona sudah cukup masif, sehingga sifatnya parsial dan kedaerahan. Semua ketentuan pelaksanaan kebijakan terkait Corona di daerah, harus dilakukan berdasarkan konsultasi dan persetuan pemerintah pusat. Hasilnya, ketidakpuasan publik pun muncul karena dengan kebijakan PSBB yang parsial, pemerintah dinilai terlalu takut mengambil resiko bagi ekonomi, terlalu sayang mengalokasikan sumber daya guna memberikan perlindungan kepada masyarakat, tetapi gegabah mempertaruhkan kesehatan.

Ketidakpuasan makin menjadi-jadi, karena di tengah angka infeksi yang meroket, serta tidak adanya tanda-tanda kurva yang melandai, pemerintah mengambil langkah New Normal. Sebagaimana yang diketahui bersama, New Normal adalah kebijakan jalan tengah, dipilih sebagai opsi untuk menjembatani keparahan penularan dan keterpurukan ekonomi, di tengah ketidakpastian kapan infeksi virus ini akan berhenti. Daripada menahan pergerakan masyarakat, pemerintah memutuskan membuka keran pembatasan. Masyarakat tidak lagi dihadapkan pada kebijakan pembatasan kegiatan yang ketat seperti sebelumnya, fasilitas publik dijinkan dibuka, dan kegiatan ekonomi boleh jalan, tetapi dengan penerapan protokol kesehatan. Faktanya, dalam banyak kasus, "protokol kesehatan" sekedar mantra. Kegiatan yang melibatkan kehadiran masyarakat dalam jumlah besar tetap susah dikendalikan dan dipastikan penjagaan jaraknya yang aman. Cuci tangan merupakan kegiatan yang paling tidak bisa dimonitor oleh alat negara. Bahkan, penggunaan masker pun masih sering lolos dari pengawasan. Pemerintah masih kewalahan. New Normal makin dianggap paradox, karena dimunculkan ketika kasus Covid-19 belum reda, bahkan menunjukkan tren kenaikan, edukasi masyarakat tidak optimal, serta penegakan protokol kesehatan sangat terbatas. Ketidakpuasan publik makin jamak muncul di permukaan, karena New Normal terlalu tidak realistis.

Tentu saja, terdapat beberapa kalangan yang melihat New Normal adalah pilihan yang tidak terhindarkan. Secara konseptual, New Normal mengajak masyarakat berdamai dengan virus, berdamai dengan krisis. Dalam istilah Handmer \& Dovers (2007: 107) pendekatan ini disebut dengan adaptabilitas dan fleksibilitas terhadap krisis, yaitu kemampuan beradaptasi dan bersikap fleksibel terhadap berbagai opsi pengelolaan krisis. New Normal didefinisikan sebagai upaya yang paling memungkinkan untuk membantu masyarakat bertahan hidup, di tengah sempitnya pilihan. Di saat sumber daya manusia di lingkaran kebijakan, serta sumber dana penopang kebijakan perlindungan tidak tersedia maksimal, New Normal dianggap sebagai pendekatan yang paling masuk akal untuk menghadapi krisis, sekaligus sebagai upaya meminimalisir keparahan krisis lain yang muncul dalam jangka menengah dan panjang, yaitu krisis ekonomi. Jika harus lockdown, akan sampai kapan. Siapa yang dapat menjamin lockdown dapat benar-benar membebaskan negara dari Covid-19, padahal setiap kasus tunggal infeksi tetap berarti penularan yang lebih besar. Alih-alih menghabiskan sumber daya yang belum tentu jaminan keberhasilannya, pemerintah memilih menerapkan New 
Normal, dengan tetap memberikan dukungan kepada kelompok masyarakat yang membutuhkan, serta mengiefisienkan pengeluaran-pengeluaran.

Segala kerumitan akibat dari pandemi Covid-19 ini makin menjadi karena, di sisi lain, pemerintah juga tidak mungkin mengandalkan bantuan negara lain. Tidak ada negara yang bebas dari interupsi Corona. Beberapa negara maju yang kerap menyalurkan bantuan untuk pembangunan di Indonesia dan penanganan bencana selama ini pun terpuruk akibat Covid-19, seperti China, Jepang, Amerika dan negaranegara Timur Tengah. Jika dalam bencana alam, seperti gempa bumi, banjir, kebakaran hutan, dan gunung meletus cakupan dampaknya hanya pada region tertentu, sehingga pemerintah provinsi lain atau bahkan negara lain yang tidak terdampak dapat mengalokasikan bantuan, Covid-19 ini mengenai dan membawa resiko bagi semua orang. Akibatnya, setiap unit pemerintahan dipaksa berkonsentrasi pada penyelesaian masalahnya sendiri.

Hal lain, tidak seperti bencana alam yang anggaran penanganannya sedikit banyak telah dialokasikan, anggaran krisis pandemi jelas tidak masuk dalam alokasi. Anggaran bencana yang disisihkan jauh dari cukup, sehingga penganggaran pandemi kali ini harus memakan banyak pos di sektor lain. Pada masa awal pandemi, pemerintah bahkan harus menyusun ulang struktur anggarannya, dan menetapkan konsentrasi pada penanganan Corona. Jelas, desrupsi Covid-19 dalam anggaran merupakan sesuatu yang belum pernah terjadi sebelumnya.

Terakhir, konteks pandemi Covid-19 ini menghadirkan kesulitan tersendiri dalam mengelola masyarakat. Beberapa pemerintah daerah telah mengupayakan untuk mendorong solidaritas sosial dalam pencegahan penularan Covid-19. Pemerintah Provinsi Jawa Tengah, misalnya, meluncurkan Program "Jogo Tonggo" untuk memberdayakan pertetanggaan sebagai basis mengatasi penularan Corona. Dengan mekanisme relasi pertetanggaan, pemerintah berharap akan ada energi tambahan untuk mengingatkan masyarakat disiplin mengikuti protokol kesehatan. Masalahnya, konsep solidaritas dalam masyarakat Jawa adalah kebersamaan, paguyuban, atau sederhananya kumpul-kumpul. Sementara, "Jogo Tonggo" mengandaikan sebaliknya, dimana definisi kebersamaan digeser menjadi saling berjauhan, sesuatu yang tidak menjadi kebiasaan masyarakat, bahkan sesuatu yang mungkin dianggap bertentangan dengan pengertian "guyub rukun". Dalam beberapa kasus, tetangga bahkan menjadi penekan bagi anggota masyarakat yang bermaksud disiplin terhadap protokol kesehatan, dengan segala dalih dan labelling yang menyertai. Di titik ini, jelas rekonseptualisasi solidaritas dan gotong royong menghadapi tantangannya sendiri. Solidaritas dalam konteks pandemi Covid-19, dengan demikian tidak sesederhana solidaritas dalam konteks bencana.

Mempertimbangkan aspek-aspek di atas, menjadi jelas bagi kita bahwa konteks pandemi Covid-19 ini memunculkan beban yang berlipat-ganda bagi kebijakan. Segala sisi seolah terkunci, dan segala pilihan yang biasanya sudah tidak banyak tersedia di kala bencana, makin terhimpit ruangnya. Beban berlipat-ganda bagi kebijakan ini memaksa kita untuk merefleksikan kembali pendekatan kebijakan yang selama ini kita percayai, yang cenderung melihat kebijakan sebagai dikotomi bisnis as usual dan kebijakan dalam situasi krisis. Pandemi bukan sekadar krisis, tetapi sudah berdimensi multikrisis. 


\section{Pendekatan Multikrisis di Masa Pandemi: Relevansi Kajian Akademik}

Merefleksikan argumentasi tentang beripat-gandanya beban kebijakan dalam konteks Pandemi Covid-19, sebagaimana sudah dijelaskan sebelumnya, kiranya relevan mengkategorikan pandemi ini sebagai kondisi multikrisis. Implikasinya, dikotomi kebijakan tidak sekedar mencakup business as usual dan krisis, tetapi juga mencakup kondisi multikrisis. Dalam hal ini, kebijakan multikrisis menjadi tawaran baru dalam diskusi kebijakan publik guna menjelaskan fenomena sosial dan politik, sebagaimana direpresentasikan dalam konteks Pandemi Covid-19.

Beberapa hal yang bisa digaris-bawahi untuk menjelaskan apa itu kebijakan multikrisis, ditarik dari refleksi pengalaman pandemi Covid-19, adalah sebagai berikut. Pertama, para pembuat kebijakan dihadapkan pada persoalan yang belum jelas definisi masalahnya apa, tetapi sudah dituntut untuk mampu menghasilkan solusi, karena dampak dari masalah tersebut jauh lebih nyata, bahkan sudah masif dan mengkhawatirkan. Kesulitan ini tidak pilih-pilih. Tidak hanya negara berkembang, negara maju dengan perangkat penelitian dan ilmuan memadai juga memerlukan waktu untuk dapat benar-benar memperoleh kejelasan tentang apa itu Sars-Cov2. Sementara riset sedang dilakukan, dampak Corona sudah meluas, dan ketika berbagai informasi sudah dapat dikumpulkan, termasuk terkait dengan vaksin, jumlah korban yang terinfeksi, meninggal, jatuh bangkrut dan mungkin tidak tertolong, sudah jauh melesat. Jika dalam penelitian bencana statistic menjelaskan, fatalitas negara maju lebih rendah menurut Handmer \& Dovers (2007: 5), dalam kondisi pandemi hal ini tidak berlaku.

Kedua, kebijakan multikrisis memaksa para pembuat kebijakan berada dalam kondisi dilematik yang serius, dimana pilihan pada hanya satu opsi menyebabkan konsekuensi yang besar, dan mungkin tidak terbayar. Perbedaannya mungkin hanya terletak pada kerangka waktu, apakah konsekuensi itu akan diterima saat ini, atau di masa yang akan datang. Lockdown dan New Normal, sebagaimana dijelaskan sebelumnya, adalah gambaran paling mudah untuk menjelaskan dilema ini.

Ketiga, kebijakan multikrisis menggambarkan situasi krisis yang dialami oleh banyak negara, setidaknya Sebagian besar negara, sehingga upaya saling membantu menjadi langkah yang tidak mudah. Jika dalam bencana alam bantuan dapat disalurkan dari negara yang tidak terdampak kepada negara terdampak, dalam konteks pandemi Covid-19 hal itu tidak mudah dilakukan. Bantuan mungkin mengair dari beberapa negara, tetapi tentu tidak cukup optimal, karena masing-masing negara fokus pada pemulihan di negara mereka sendiri.

Keempat, kebijakan multikrisis tidak punya banyak ruang untuk menduplikasi pendekatan yang diterapkan dalam kebijakan-kebijakan krisis lainnya sebelumnya, utamanya yang terkait dengan pengelolaan masyarakat. Jika dalam konteks krisis yang lain para pembuat kebijakan dapat dengan mudah memformulasikan program berbasis solidaritas sosial, dalam kondisi multikrisis, hal ini ternyata tidak sesederhana yang dibayangkan. Kata solidaritas, yang selama ini manjur untuk mengatasi krisis yang diakibatkan oleh bencana, sudah terlalu identik dengan kedekatan, kebersamaan dan keintiman sosial. Sementara, kondisi pandemi memaksa masyarakat melakukan sebaliknya, yaitu jaga jarak. Definisi solidaritas, dalam hal ini memerlukan reka-ulang, tidak hanya karena ia terkait dengan perubahan perilaku dan budaya, tetapi juga 
pemahaman di alam bawah sadar. Tidak hanya bagi pembuat kebijakan, tentu saja hal ini juga sekaligus menjadi tantangan bagi para ilmuan sosial.

Empat aspek di atas setidaknya dapat menjadi titik balik bagi kita untuk merefleksikan kembali pemahaman kita tentang apa itu kebijakan. Selain itu, ke-empat poin di astas juga akan membantu kita mempertanyakan kembali relevansi dikotomi kebijakan menjadi kebijakan business as usual dan kebijakan dalam kondisi krisis. Dalam hal ini, pendekatan multikrisis adalah tawaran bagi pengkaji kebijakan untuk melangkah lebih jauh dari dikotomi business as usual dan pendekatan krisis.

\section{Penutup}

Artikel ini berargumen bahwa konseptualisasi kebijakan kedalam dikotomi business as usual dan situasi krisis tidak cukup menjelaskan konteks pandemi Covid-19. Kebijakan dalam situasi krisis sebagaimana yang dijelaskan para ilmuan pengkaji kebijakan selama ini hanya membayangkan krisis dalam skop yang terbatas, yaitu daerah tertentu, negara tertentu atau wilayah regional tertentu. Ternyata krisis dapat juga terjadi secara global, dengan penyebab non-struktural yang tidak mudah dikendalikan, serta penuh ketidak-pastian, baik dalam bentuk kejelasan informasi, maupun rentang waktu yang diperlukan untuk keluar dari krisis.

Konteks pandemi Covid-19 juga memberikan tekanan yang berkali-kali bagi kebijakan, sehingga pilihan resolusi yang tersedia tidak hanya sedikit, sebagaimana kebijakan dalam konteks bencana, tetapi juga makin sempit. Dilema-dilema yang dibawa membawa kesulitannya masing-masing dengan konsekuensi yang tidak kecil. Tidak ada formula pasti yang paling efektif, sebagaimana perdebatan lockdown dan New Normal, karena satu formula selalu mengandung sedikit penyelesaian tetapi segudang kelemahan didalamnya, jika dihadapkan pada keterbasatan sumber daya yang dimiliki.

Oleh karena itu, artikel ini melihat, konteks pandemi Covid-19 ini menjelaskan perspektif kebijakan multikrisis, sebagai perluasan dari dikotomi kebijakan yang selama ini ada. Tentu saja, tawaran konseptual ini layak diperdebatkan ditindaklanjuti dengan kajian empiris yang mendalam. Yang jelas, konteks pandemi Covid-19 ini banyak memaksa kita untuk merefleksikan kembali teori-teori kebijakan yang selama ini sudah kita percayai.

\section{Ucapan Terima Kasih}

Penulis mengucapkan terimakasih kepada Fakultas IImu Sosial dan IImu Politik yang telah memberikan bantuan pendanaan dalam penelitian ini.

\section{Pendanaan}

Tulisan ini merupakan hasil penelitian literature yang menjadi bagian dari proyek penelitian "Resiliensi Masyarakat Urban dalam Konteks Pandemi" yang didanai DIPA Fakultas Ilmu Sosial dan Ilmu Politik Universitas Diponegoro Tahun 2020.

\section{Daftar Pustaka}

Boin, A., Hart, P., \& Kuipers, S. (2018). The Crisis Approach. Handbook of Disaster Research. Handbooks of Sociology and Social Research. Springer, Cham.

Boin, A., Stern, E., \& Sundelius, B. (2016). The Politics of Crisis Management: Public 
Leadership Under Pressure. Cambridge University Press.

Borodzicz, E. (2005). Risk, Crisis and Security Management. Wiley.

Carroll, T. (2016). Project Delivery in Business as Usual Organizations. CRC Press.

Chirot, D. (2011). A Turning Point or Business as Usual. Business as Usual: The Roots of the Global Financial Meltdown, 113-136.

Craig, M. (2018). On 'The Other Crisis': Diagnosing the Socio-Ecological Crisis. In The coming crisis (pp. 17-24). Springer.

Devlin, E. S. (2006). Crisis Management Planning and Execution. CRC Press.

Gilpin, D. R., \& Murphy, P. J. (2008). Crisis Management in a Complex World. Oxford University Press.

Handmer, J., \& Dovers, S. (2007). The Handbook of Disaster and Emergency Policies and Institutions. London: UK: Earthscan.

Rodríguez, H., Donner, W., \& Trainor, J. (2018). Handbook of Disaster Research: Second Edition. Cham, Switzerland: Springer.

Wong, W. N. Z., \& Shi, J. (2018). Business Continuity Management Organizations: The Models of Implementation. In The Routledge Companion to Risk, Crisis and Security in Business (pp. 62-79). Routledge.

\section{Tentang Penulis}

\section{Laila Kholid Alfirdaus}

Dosen Departemen Politik dan Pemerintahan Fisip Undip, memiliki fokus riset pada kebijakan publik, dengan lingkup sub-kajian yang mencakup analisis kebijakan, politik perencanaan, politik evaluasi, dan politik pemberdayaan.

\section{Teguh Yuwono.}

Dosen Departemen Politik dan Pemerintahan Fisip Undip, memiliki fokus pada kajian inovasi kebijakan, tatakelola pemerintahan, dan kajian kepemimpinan politik. 